\title{
China's Belt and Road Initiative: Will it Make or Mar Development in the Central and West Africa Subregions?
}

\author{
William G. Dzekashu \\ Multifamily representative at the U.S. Department of Housing and Urban Development's \\ Office of Recapitalization, USA
}

Julius N. Anyu

Professor at the School of Business and Public Administration, University of the District Columbia, USA

Received: Sep. 2, 2020 Accepted: Oct. 11, 2020 Online published: Oct. 25, 2020

doi:10.5296/jpag.v10i4.17876 URL: https://doi.org/10.5296/jpag.v10i4.17876

\begin{abstract}
The West, chiefly Europe, left political footmarks in Africa from the Colonial Era, along with varying economic footprints and surviving engagements in the immediate Post-colonial Era. However, the relationships between Africa and her former colonial masters have hardly yielded much to the former following the wave of independence, leading to the perception of failed relationships. This perception of failure to deliver on their undertakings has left Africa with only one option-China. The latter has been addressing some of Africa's urgent infrastructure needs in return for natural resources and agricultural products. These engagements on the surface appear to be good business, but on further examination seem questionable notably as it relates to debt distress on vulnerable economies. To increase her footprint within the continent, China extended her Belt and Road Initiative (BRI) to most African nations who have signed a memorandum of understanding for future development projects. Though the commitments usually are unspecified, China's investments have seen rapid growth since the early 2000s, largely owing to the implementation of the BRI. The memoranda have had the potential to strengthen ties with partner nations. The expansion to include Africa in its economic participation in the BRI has left the West questioning China's motives while reinforcing suspicions about possible future US-China conflict. The impact of BRI on the African continent is quite visible in all the subregions, especially in their improved gross domestic products. A burning question has been whether these partnerships
\end{abstract}


represent win-win relationships for sustainable growth or debt-growth dynamics.

Keywords: Africa, BRI, China, debt, development, FDI Flow, FDI Stock, FOCAC, GDP, infrastructure, loans, trade, United States

\section{Introduction}

Africa's need for infrastructure development and modernization principally in the areas of hydropower generation, railroad transportation, information and communications technology (ICT), and oil and gas, sectors validates Africa's need for a proven competent partner. This need for infrastructure development in Africa matched China's quest for natural resources and agricultural products. African nations for the most part who required foreign capital investments and partnerships for infrastructure implementation, turned to China rather than the West for collaboration. The compelling reasons for aligning with China are tied to the fact that there are no strings attached to the commitments; and the failures of the West to deliver on agreements entered in the Post-colonial Era left Africa without visible development (Anyu \& Dzekashu, 2019).

China's involvement in Africa before 1980 - described “... as a spin-off from Chinese geopolitical policies in Asia," (Anyu \& Dzekashu, 2019, p. 173), was primarily centered on exporting revolution (communism and revolutionary war), an ideology-driven policy (Sun, 2016). From the 1980s onwards, China's interest in Africa diminished while she embarked on economic reforms centered around domestic economic development and opening to the West. Once China started engaging with Africa, it only took eight years for her trade with Africa to grow at an annual rate of 10\%; placing her in the position of second-largest trade partner in the continent after the United States (US). This growth has been exponential following the Forum on China-Africa Co-operation (FOCAC) in 2020, after which foreign direct investment (FDI) rose to US\$46 billion in 2018 (McGregor \& Havenga, 2019).

Many engagements with China on the face appear to be win-win; however, on careful assessment, the following questions arise: do these agreements represent good business for Africa? What is a viable alternative to China? Finding the terms of agreements and data on China's overseas activities tend to be challenging because the information is not centralized. Chinese investments in Africa continue to experience a steady rise, and though foreign domestic investment (FDI) flows were small by global standards, the ratio of FDI to gross domestic product (GDP) was high, therefore signaling the importance of FDI to the continent's economic growth. According to data provided by Johns Hopkins University (JHU) School of Advanced International Studies (SAIS) China-Africa Research Initiative (2020) the total FDI stock between 2003 and 2018 in Central Africa was US\$38.59 billion, while in West Africa was US\$52.81 billion of the total US\$287.96 billion. Total FDI flows in the same period in Central Africa were US $\$ 4.77$ billion and in West Africa were US\$7.04 billion of the total US\$39.07 billion.

China's interest in Africa can be summarized as follows: (1) quest for natural resources, (2) search for fuel to feed her growing economy, and (3) reinforcement of political influence. The strategy has been to focus primarily on the infrastructure needs in Africa. During the FOCAC 
in 2018, China announced her renewed commitment to deliver US\$60 billion in financial support to Africa, thereby demonstrating her interest in expanding her footprint within the continent through diversification of sources of funding through collaborative activities and joint ventures, and by issuing low-interest loans through the Export-Import Bank of China (EIBC).

\section{Problem Statement}

Africa's dependence on external financing stems from her dire need for private investment (Risberg, 2019). Accordingly, the African Development Bank identified a funding gap of US\$87-112 billion, and thus launched an investment platform in 2018 to address this shortage. This investment gap offered a unique opportunity for the US and the West to engage with their African partner-nations to offer an alternative to what has become questionable Chinese investment practices. Though the impact of China's business engagements in Africa is in part positive, the impacts of US investments in the continent are uncertain in per capita income terms. The US has injected over US\$1 trillion into partner economies in Africa (Risberg, 2019), and continues to engage in development efforts within the continent.

Since launching the Belt and Road Initiative (BRI) in 2013, there is evidence of positive progress in infrastructure connectivity, railway construction, energy pipelines, and electricity generation (Jin, 2017). Despite this seeming success, China has come under intense criticism from the West especially over engagements in Africa. The skepticism over BRI commitments has only intensified because the terms of engagement are largely vague, leading to apprehensions of risks to vulnerable economies. Specifically, BRI raises the risk of debt distress in some borrower countries (Hurley, Morris, \& Portelance, 2018), an issue that the West continues to stress. However, this perception by the West, on the one hand, conflicts with the views of China and most African nations who have benefitted from these engagements and argue that China has stood in the gap as an alternative to the West. The query that this essay seeks to tackle is whether engagements under BRI lead to positive or adverse development outcomes in the Central and West Africa Subregions. There is much focus on the possible negative outcomes of the engagements in Africa tending to shroud the success of developmental projects.

\section{Objective and Scope}

The objective of this essay is to present an unbiased synthesis of existing literature relating to BRI. Besides, the paper provides statistic on BRI projects in Africa with keenness to countries located in the Central and West Africa subregions defined by the United Nations as follows; Central Africa: Cameroon, Central Africa Republic, Chad, Democratic Republic of Congo, Equatorial Guinea, Gabon, Republic of Congo and São Tomé and Príncipe; and West Africa: Benin, Burkina Faso, Cape Verde, Côte d'Ivoire, Gambia, Ghana, Guinea, Guinea Bissau, Liberia, Mali, Mauritania, Niger, Nigeria, Senegal, Sierra Leone, and Togo. The paper further provides project assessment and discussion of the economic outlook in select nations within the identified subregions.

\section{Definition of Terms}


Below are definitions peculiar to international investments and trade that could provide additional context for understanding.

Foreign Direct Investment (FDI) is an investment made by a firm or individual in one country into business interests located in another country. Generally, FDI takes place when an investor establishes foreign business operations or acquires foreign business assets in a foreign company.

Foreign Direct Investment (FDI) stocks measure the total level of direct investment at a given point in time, usually at quarterly, semi-annually, or on annual basis. The outward FDI stock is the value of the resident investors' equity in and net loans to enterprises in foreign economies. The inward FDI stock is the value of foreign investors' equity in and net loans to enterprises resident in the reporting economy. FDI stocks are measured in USD and as a share of GDP. FDI creates stable and long-lasting links between economies.

Foreign Direct Investment (FDI) flows record the value of cross-border transactions related to direct investment during a given period, usually a quarter or a year. Financial flows consist of equity transactions, reinvestment of earnings, and intercompany debt transactions.

Gross Domestic Products (GDP) is the monetary value of all finished goods and services made within a country during a specific period. GDP provides an economic snapshot of a country and is used to estimate the size of an economy and growth rate. GDP can be calculated in three ways, using expenditures, production, or incomes.

\section{Methodology}

The lack of publicly reported sources on BRI pipeline projects has led to creative methods of assessing the impact of partner commitments. The approach used by Hurley et al. was to collate official publicly reported sources to build project lending pipelines for nations identified as highly vulnerable to debt distress (2018). This information was then triangulated by media and other additional sources. Zhai's approach on another hand was to investigate the macroeconomic impact of BRI by implementing a global computable general equilibrium model (2017). Both models are an attempt to employ a quantitative approach to determine the debt impact of BRI on member countries, and the methods are not without limitations. The lack of transparency in reporting credit activities within project pipelines present a risk of inaccuracy in reporting. This essay utilizes a systematic literature review to synthesize findings from different research projects with available reporting. A Systematic literature review is a method and process for identifying and appraising relevant research, as well as for collecting and analyzing data from the said research (Snyder, 2019).

\section{Belt and Road Initiative Footprint in Africa by Subregions}

BRI is a multi-billion infrastructure investment platform. The belt refers to the overland interconnecting infrastructure corridors which consist of two parts: (1) the Silk Road Economic Belt (SREB), and (2) 21st Century Maritime Silk Road. SREB refers to the land connection through Central Asia to Europe which establishes six land corridors connecting China's interior to Central Asia and Europe; including railroads to Europe, oil and gas 
pipelines from the Caspian Sea to China, and a high-speed train network connecting Southeast Asia to China's eastern seaboard. The 21st Century Maritime Silk Road refers to the connection through Southeast Asia, South Asia, Africa, and, finally, Europe; establishing three Blue Economic Passages knitted together through a chain of seaports from the South China Sea to Africa, directing trade to and from China. Combined, they are known as One Belt, One Road (OBOR), or more commonly as BRI. This initiative guides Chinese policies towards the African geographic periphery (Anyu \& Dzekashu, 2019), directly supporting many elements of China's national security strategy. OBOR at a macro level sought to restructure the world economic order in ways only advantageous to Beijing's drive for superior power status (Anyu \& Dzekashu, 2019). It should be noted that not all projects implemented in Africa by China are accomplished under the banner of BRI

BRI was developed by China to strengthen Beijing's economic leadership through engagement in vast infrastructure development (Swaine, 2015) projects. By 2019, approximately 40 out of 55 African nations along with the African Union-had signed an MoU with Beijing for financing and infrastructure construction (Dahir, 2019). The countries that have not signed up may have concerns tied to the imposition of military and security requirements and the need for protection of Chinese nationals over locals, and other reasons tied to the diplomatic past with China and suspicion of the unclear implications of BRI (Dahir, 2019). BRI has forged intertwining economic, political, and security ties between Africa and China, essentially advancing Beijing's geopolitical interests (Anyu \& Dzekashu, 2019). These engagements are attractive to African nations because they do not impose any conditions. Some regions have succeeded in leveraging financing and technical implementation from China for major projects (see Figure 1) than others between 2014 and 2018.

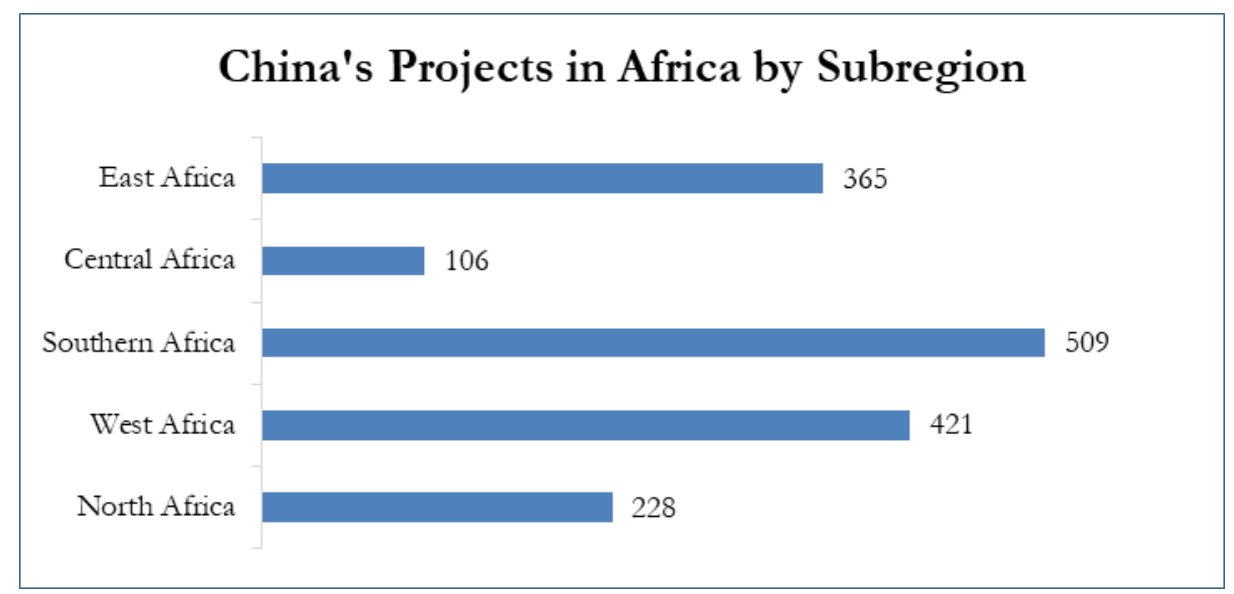

Figure 1. China's Construction Projects in Africa by Subregion

Source: Deloitte: https://www2.deloitte.com/za/en/pages/energy-and-resources/ articles/africa-construction-trends-report.html.

Consider the 2019 data in Tables 1 and 2; the FDI flows between 2003 and 2018 to the two 


\section{Macrothink}

Journal of Public Administration and Governance

ISSN 2161-7104

2020, Vol. 10, No. 4

subregions - Central Africa: $12.2 \%$, with about $55.38 \%$ going to the Democratic Republic of Congo and the least to São Tomé and Príncipe- 0.01 percent; and West Africa: $18 \%$, with about $41.89 \%$ to Nigeria, and the least -0.03 percent to Burkina Faso. Combined, both subregions of Central and West Africa received just under a third of the FDI (stock $=31.8 \%$ and flow $=30.3 \%$ ) to Africa.

Table 1. Chinese FDI Flow to Central Africa (2003-2018)

\begin{tabular}{lll}
\hline Country & FDI Flow in US\$ Billion & Percentage \\
\hline Cameroon & 2.13 & $5.51 \%$ \\
Central Africa Republic & 0.48 & $1.25 \%$ \\
Chad & 3.06 & $7.94 \%$ \\
Republic of Congo & 6.60 & $17.10 \%$ \\
Democratic Republic of Congo & 21.37 & $55.38 \%$ \\
Equatorial Guinea & 2.69 & $6.97 \%$ \\
Gabon & 2.66 & $5.86 \%$ \\
São Tomé and Príncipe & 0.01 & $0.01 \%$ \\
\hline Total & 38.59 & $100.00 \%$
\end{tabular}

Source Data: JHU SAIS China-Africa Research Initiative, February 2019, http://www.sais-cari.org/s/FDIData_19Feb2020.xlsx

Table 2. Chinese FDI Flow to West Africa (2003-2018)

\begin{tabular}{lll}
\hline Country & FDI Flow in US\$ Billion & Percentage \\
\hline Benin & 0.86 & $1.62 \%$ \\
Burkina Faso & 0.01 & $0.03 \%$ \\
Cape Verde & 0.13 & $0.24 \%$ \\
Cote d'Ivoire & 1.42 & $2.69 \%$ \\
The Gambia & 0.05 & $0.09 \%$ \\
Ghana & 9.79 & $18.51 \%$ \\
Guinea & 3.95 & $7.47 \%$ \\
Guinea-Bissau & 0.48 & $0.91 \%$ \\
Liberia & 2.12 & $4.02 \%$ \\
Mali & 2.57 & $4.86 \%$ \\
Mauritania & 1.30 & $2.46 \%$ \\
Niger & 4.42 & $8.37 \%$ \\
Nigeria & 22.15 & $41.89 \%$ \\
Senegal & 1.26 & $2.39 \%$ \\
Sierra Leone & 1.31 & $2.48 \%$ \\
Togo & 1.04 & $1.97 \%$ \\
\hline Total & 51.44 & $100.00 \%$
\end{tabular}

Source Data: JHU SAIS China-Africa Research Initiative, February 2019, http://www.sais-cari.org/s/FDIData_19Feb2020.xlsx

Figure 2 shows the breakdown of FDI flow, while Figure 3 shows the breakdown of FDI 


\section{Macrothink Institute ${ }^{\mathrm{TM}}$}

stock by the two subregions of Central and West Africa compared to the rest of the continent for the period 2003 to 2018. The observations in FDI during the same period is upward trending in China's engagements within the subregions and the entire continent. This upward trend further confirms that China has become the main player in Africa. The subregions with the most projects implemented by number and value are Southern Africa and West Africa, while Central Africa trails.

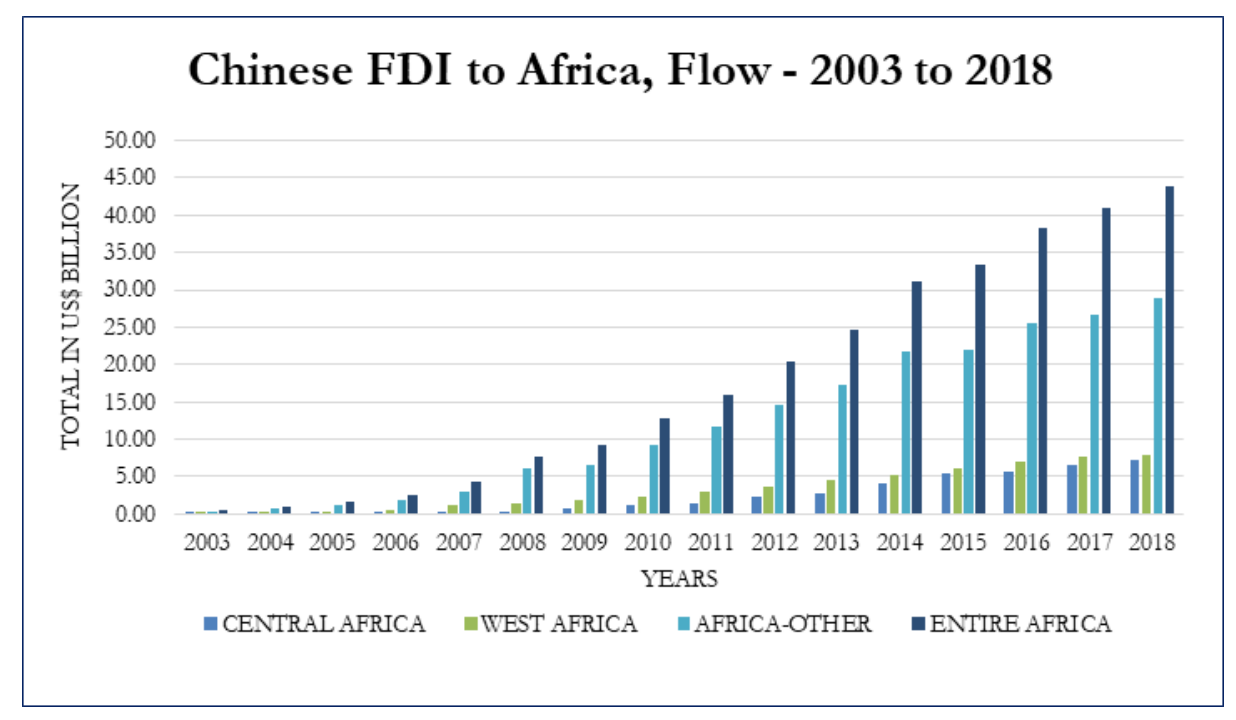

Figure 2. Chinese FDI Flow to Africa (2003-2018)

Source Data: JHU SAIS China-Africa Research Initiative, February 2019, http://www.sais-cari.org/s/FDIData_19Feb2020.xlsx

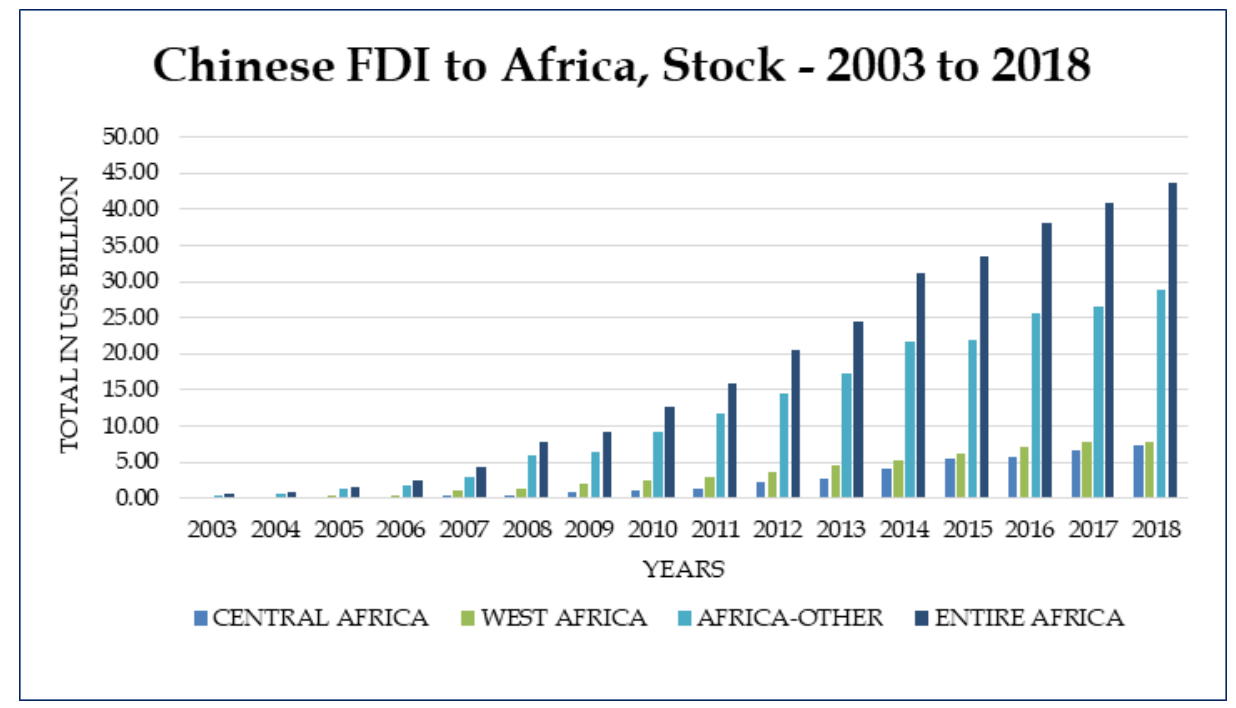

Figure 3. Chinese FDI Stock to Africa (2003-2018)

Source Data: JHU SAIS China-Africa Research Initiative, February 2019, http://www.sais-cari.org/s/FDIData_19Feb2020.xlsx

\section{Highlights of Select BRI Investment Projects in Central and West Africa}


Below is a brief appreciation of some key BRI projects undertaken in three countries in the Central and West Africa subregions, most of which are in line with the African Union's Agenda 2063 seeking to link up all 54 African nations through transportation infrastructure projects, including modern highways, airports, and high-speed railways (Metwally, 2019). The countries discussed are Cameroon, Ghana, and Nigeria, - the biggest benefactors of BRI within the two subregions.

\section{a. Cameroon - Kribi-Lolabe Double Carriage Road and Kribi Deep Seaport Projects}

Cameroon accounts for the largest share of BRI projects in the Central Africa subregion-26 total representing $56.4 \%$ of projects by value. The government owns $53.8 \%$ of the projects, with the majority in the Transport sector. The Kribi-Lolabe 23.9 -mile $(38.5 \mathrm{~km})$ double-carriage highway road, constructed by a Chinese firm and valued at US\$456 million represents one of five road infrastructure projects in the region (Labuschagne, Dedasaniya, Davies, \& Essop, 2018). At the completion of the highway, the Cameroon government entered an operations and maintenance agreement with China Harbor Engineering Corporation (CHEC).

The Cameroon government also launched a project for the construction of an autonomous transit port in the town of Kribi (developed in three phases); the largest deep-water port in central Africa and one of the biggest Chinese investment projects anywhere in the world. The Chinese government pledged to finance $85 \%$ of the construction through the EIBC, while the government of Cameroon is responsible for financing the difference. The projected cost at completion is projected at US\$1.3 billion ( $€ 1.1$ billion). The state-run CHEC oversaw the construction of the first phase (Schenkel, 2018), and construction of the second phase commenced one year late in 2018 and is expected to be delivered in 2023. Cameroon has other high-value projects mining sector pipeline (Ngaoundal \& Minim-Martap-US\$6 billion, Mbalam-Nabeba-US\$ 4.7 billion, and Nkamouna-Mada-US\$830 million); and the Memve'éle Hydroelectric Dam valued at CFAF 365 billion (or US\$654.3 million) and Lom Pangar Projects (valued at US\$490 million) amongst others financed by the Eximbank where Cameroon again opted for Chinese versus Western Financiers (Chen \& Landry, 2016).

The GDP of Cameroon in 2019 was US\$38.76 billion (representing 0.03 percent of the world's economy) according to official data from the World Bank and projections from Trading Economics. The country has enjoyed steady growth and developed an ambitious plan to be an emerging economy by 2035. Fitch Ratings recently revised the outlook on Cameroon's Long-Term Foreign-Currency Issuer Default Rating (IDR) from Stable to Negative and upheld the rating at 'B'. The reason for this revision is tied to the projected contraction in the economy by 2.1 percent in 2020 largely as a result of delays in infrastructure projects implementation, due to financing constraints, and moderate coronavirus (COVID-19) containment measures that weakened performance in the construction, transport, and trade sectors; fall in crude oil prices and suspension of activities at the lone oil refinery-SONARA, and ongoing security challenges in the English-speaking minority region and the Far North region of the country that have weighed heavily on agricultural production. It is forecasted that the fiscal deficit on a commitment basis is likely 
to widen to $5.3 \%$ of the GDP in 2020, and the effect will be a $14 \%$ reduction in government revenues. These few reasons are indicators that Cameroon currently has vulnerabilities that if not monitored could lead to debt distress. Cameroon in 2019, benefitted from a write-off from China on unpaid debt worth US\$78.4 million that was due in 2018 (Belt \& Road News, 2019). Cameroon's total debt is CFAF 5.8 trillion (or US\$10 billion), about a third of which is owed to China, according to the International Monetary Fund (IMF). This gesture of debt-relief by China is viewed by Cameroon as a positive move to support its development agenda.

\section{b. Ghana - Block Offshore Integrated Oil \& Gas Development and Ada Estuary Tidal Power Plant Projects}

Ghana boasts of some 30 projects, valued at US $\$ 10$ billion under the banner of BRI. The Block Offshore Integrated Oil and Gas Development project located about 60 kilometers off the coast of Western Ghana is valued at US\$7 billion and has since 2017 entered production. It is the only of non-associated gas development project entirely dedicated to the domestic market in sub-Saharan Africa. The block according to Badu (2019), has reserves of about 40 billion square meters non-associated gas and 500 million barrels of oil (Labuschagne et al., 2018).

The engagement between China and Ghana in the Ada Estuary Tidal Power Plant valued at US $\$ 4$ billion (since commissioned) also shows the strategic relationship between both countries, especially in infrastructure development. In 2019, in the words of Yoofi Grant - the Chief Executive Officer of Ghana Investment Promotion Center, that China's notion of developing trade lines along infrastructure was important for Ghana, which is strategic about it (Xinhua, 2019). Ghana has a robust developmental plan shown in its Ghana Beyond Aid agenda (Belt \& Road News, 2019). Another project in the pipeline is the Tema Port Expansion Project valued at US\$1.5 billion.

The GDP of Ghana in 2019 was US\$66.98 billion. The economy according to Focus Economics shrunk markedly in the second quarter as COVID-19 and associated containment measures weighed heavily on domestic activity and foreign demand (Focus Economics, 2020). Although the economic outlook of the country was upgraded from negative to stable, Standard and Poors (S\&P) Global Ratings downgraded her credit rating from B to B- in mid-September. The economy, however, is projected to expand 0.5 percent in 2020 and 4.8 percent in 2021. In 2019, China agreed to provide Ghana with a debt relief of US\$36 million, while at the same time extended a grant to her in the amount of US\$43 million where no specifics were provided (Orlander, 2019). This relief is insignificant compared to Ghana's debt of US $\$ 38.9$ billion. The IMF suggests that Ghana has a debt-to-GDP ratio of $58 \%$ raising concerns about her ability to service the loans if they stay on the same path.

\section{c. Nigeria - Ajaokuta-Kaduna-Kano Gas Pipeline, Lagos-Kano Rail, and Lagos-Badagry Expressway Expansion Projects}

Nigeria is home to the greatest number of projects executed in West Africa by China under the BRI banner, with 32 projects representing 30.5\% projects in the subregion, valued at US $\$ 63$ billion. The US\$2.8 billion Chinese-funded Ajaokuta-Kaduna-Kano Gas Pipeline 
project with a capacity to carry natural gas between the southern and northern parts of the country is important to Nigerians (Nyabiage, 2020). China Civil Engineering Construction Corporation received a contract award of US\$6.68 billion to work on a major segment of a railway linking the country's commercial hub Lagos, in the southwest, and Kano in the north (Radford, 2018). This project was broken into segments for implementation (Labuschagne et al., 2018). According to Odutola (2019), Chinese companies have a current investment in Nigeria worth over US\$20 billion. Other projects include the Lagos-Badagry Expressway Expansion project valued at US\$1.9 billion, Lagos-Ibadan railway, a 27.5-kilometer Marina-Iddo-Okokomaiko road construction and Lagos Light Rail project and $\$ 600$ million for four international airport terminals), hydropower (contract for construction of hydroelectric power plants at Mambilla, Gurara, and Zungeru).

Nigeria has the largest economy in Africa with a GDP in 2019 of US $\$ 448.12$ billion (Trading Economics, 2020). At its peak in 2014, the GDP was US\$568.5 billion. This GDP was initially projected to rise by 2.9 percent in 2020 and 3.3 percent in 2021 . However, with the emergence of the COVID-19 pandemic, the World Bank forecasted a decline of -3.2 percent for 2020 - a five percentage point drop from previous projections. The GDP value of Nigeria represents 0.37 percent of the world economy. Many Nigerians lost employment due to the COVID-19, combined with lower volumes of exports such as oil, her economy contracted by 6.1 percent posted in the second quarter of 2020 (Kazeem, 2020). Unemployment has also risen by $27.1 \%$ of the workforce, representing (21.7million Nigerians). FDI stock from the U.S. into Nigeria was US\$5.8 billion in 2017, according to the U.S. Trade Representative (Shinn, 2017), while Chinese FDI stock was US\$4.7 billion according to McKenzie (Cook, 2019). However, a significant chunk of U.S. FDI in Nigeria and the continent go into the resources sector. Figure 4 shows a comparison of FDI flows to Africa from principally the US and China, demonstrating that China has surpassed the US in investment commitments to Africa.

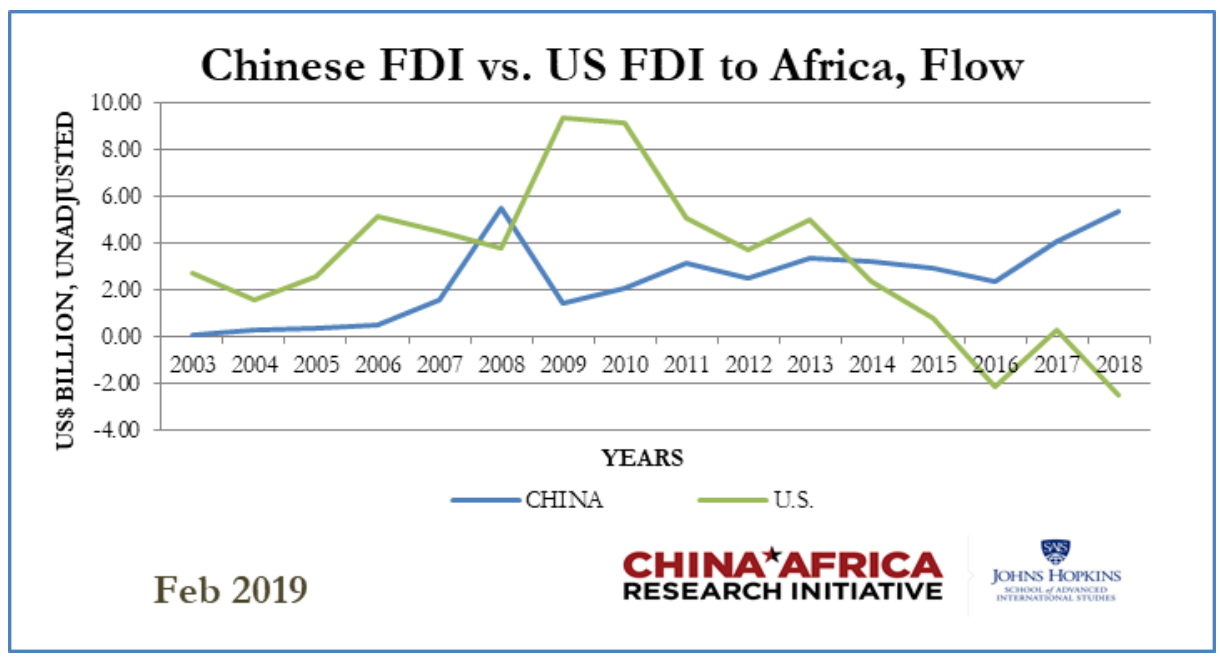

Figure 4. Chinese vs US FDI Flow to Africa (2003-2018)

Source Data: JHU SAIS China-Africa Research Initiative, February 2019, http://www.sais-cari.org/s/FDIData_19Feb2020.xlsx 


\section{Impact of BRI on Local Enterprise}

Recipients of China's concessional loans are usually requested to source at least half of procurement from Chinese firms. The Organization for Economic Cooperation and Development recommended the untying of aid to less-developed nations because they viewed it as a more efficient way to deliver aid, and to reduce the administrative burden for both donors and recipients (Cheng, Fang, \& Lien, 2012). This approach over which China has been rebuked was also used by Italy in $92 \%$ and Canada in $68 \%$ of the projects they financed in less developed nations. So, is it not fair to ask whether if what is good for the goose not good for the gander?

BRI in Africa has been described as complicated and contentious in nature because it is difficult to separate positive economic outcomes from the negative. For the most part, the West has continued to view the commitments under BRI with suspicion, because the terms of engagements are fuzzy; however, the E.U. could easily join hands to improve the capacity of Chinese investors in Africa for the benefit of the continent and for greater global economic connectivity.

\section{a. Capacity Building and Human Capital}

BRI has created an economic, political, and security nexus between Africa and China, and the latter's presence in Africa continues to be viewed with distrust; perceived mostly as profit-driven instead of ideologically based. At the inception of engagements in Africa, China provided labor at all levels for support programs bringing their nationals as temporary workers-medical personnel to serve in the hospitals and clinics; agro-technicians to work on agricultural projects including establishing farms and agricultural, and training stations (Anyu \& Dzekashu, 2019). This approach to disregarding the local workforce led to an outcry. This protest would lead to China changing its approach and engaging locals. In 2009, for example, China launched the 20+20 Cooperation Plan; in which 20 higher education institutions in China partnered with local African universities to facilitate academic exchange; a project supported by the United Nations Educational Scientific and Cultural Organization who joined the initiative to support university partnerships (Benjelloun, 2015). New initiatives that demonstrate China's intent to engage in capacity building can be seen in the creation of the China-Africa Think Tank forum organized under FOCAC such as the 10+10 Partnership Plan (Anyu \& Dzekashu, 2019).

\section{b. Ethics and Social Responsibility}

For China to succeed in creating mutually beneficial economic opportunities, it is imperative for its multinational businesses to address environmental and social challenges, opportunities, and risks that arise and to act responsibly while responding to the needs of the African markets. Among other things, China must ensure that provisions to safeguard the environment and health of African workers are considered. Tying conditions on investment agreements could help curb graft. Consider the example of the Cameroon Kribi deep-water port where it was anticipated that the project would generate economic activities and increase maritime traffic in the Central Africa subregion. To accomplish this project, the government 
of Cameroon applied eminent domain laws that allowed for the takeover of the village of Lolabe which accommodated some 300 inhabitants. The plan was to compensate the indigenes the sum of $€ 36$ million (US\$42.86 million) for resettlement; however, only $€ 22$ million (US\$26.19 million) was disbursed, while the balance was embezzled by corrupt politicians (Schenkel, 2018). There are two main problems from this engagement; a lack of commitment to social responsibility and segregated employment that has not benefitted locals. This lack of commitment to transparency in investment agreements puts Africa in a survival state for the most part.

\section{c. Security}

China's engagement in Africa does not enjoy majority domestic support, especially with growing concerns about economic sustainability in nations where there are massive infrastructure projects being implemented. This domestic backlash is also echoed in the nations concerned. The rise in hostilities such as in Ethiopia, Kenya, Tanzania, Uganda, and Zambia (Nantulya, 2019), and the local costs of sustaining security continues to have negative impacts on BRI. In 2018, many African leaders signed to the China-Africa Action Plan which required member-nations to guarantee the security of domestic projects, nationals, and companies; and to prioritize their security in intelligence, military, and police cooperation.

\section{Future Implications of BRI}

The African continent receives lower FDI inflows than any other region in the world. China on her part has continued to expand her footprint in Africa by partnering with more nations under the BRI infrastructure investment platform with positive economic implications for developing nations, though consistently overshadowed by political and national security concerns. BRI is China's one-hundred-year grand plan, which is currently threatened by staggering challenges (Deng, 2019); thereof which are perceptible: (1) development sustainability in Africa, (2) debt distress on vulnerability nations, and (3) possible conflict between China and the United States.

China is focusing on its commitment to BRI at the expense of long-term sustainability and the breakdown of BRI programs in certain countries, coupled with China's economic slowdown resulting from the trade war with the US has raised serious doubts about BRI's long-term survivability. According to Deng, the sustainability of the BRI will depend largely on how China manages geopolitics and geoeconomics. Beyond high politics, the BRI is plagued by debt and environmental issues, and given its centrality to Chinese domestic and foreign policies, Beijing is likely to do its utmost to address issues (2019) about alignment with the lending culture of Bretton Woods institutions where transparency is at the forefront.

China's BRI hopes to deliver infrastructure financing to its member nations to a value of trillions of dollars. The annual economic output of the member countries is roughly US\$25 trillion, with China accounting for some 45\%. China's lending practices, which are often direct to sovereign borrowers invokes the risk of debt distress in economies identified as vulnerable. BRI countries in Africa most at risk of debt distress based on their credit ratings 
are Djibouti, Egypt, Ethiopia, and Kenya. Of these four, Djibouti stood out as most at risk of debt distress due to future BRI-related financing. These countries were identified as risky based on analysis and judgments on recent research that shows a statistically significant threshold effect with rising debt-to-GDP ratios beyond 50-60\%.

Immediately Beijing announced her OBOR initiative, the global reaction was immediate and pronounced, as her rise appeared to challenge the plans of the West. Although collectively western countries still appear to be more important to African economies than China is single-handed, Beijing has become the single-most-important bilateral economic partner in many countries, giving the optic of challenging the US and European Union (E.U.) for economic leadership across the continent (Shinn, 2019). The US has been mostly preoccupied with the bleak picture or ethical issues related to China's approach that it seems to be missing out on possibilities to be an active partner in the development of Africa alongside China (Risberg, 2019). The US in 2000 under President Bill Clinton launched the Africa Growth and Opportunity Act (AGOA) to expand trade mainly in sub-Saharan Africa, stimulate economic growth, and encourage economic integration into the global economy. The current US administration through the International Development Finance Corporation (IDFC) has doubled her investment efforts in Africa to US\$60 billion with plans to take equity stakes and other financial tools to invest in local businesses. This effort created a fund for infrastructure development and subsequently, the Blue Dot Network initiative-a competing vision for global connectivity focused on the Indo-Pacific sphere was rolled-out (Deng, 2019). In 2018 the leading AGOA import categories; crude oil, minerals and metals, and transportation equipment performed poorly, while textiles and apparel, agricultural products, chemicals, and related products experienced growth. After a peak in 2014, FDI in Africa from the US dropped to US\$47.80 in 2018. The US-China economic decoupling and geopolitical rivalry risk rupturing the global connectivity that BRI seeks to build on (Deng, 2019).

\section{Recommendations}

Rather than continue to castigate China over her single-handed approach to credit lending and infrastructure development under her BRI, the West needs to appeal to China's sense of global citizenship so that her investment practices would align with rhetoric about development. This approach will also protect her in the event of default where the power of collective action can protect her interest (Hurley et al., 2018). African nations in general see in China, a reciprocal partner whose approach is very different from the West, where credit terms are tied to ethical strings. Notwithstanding the West's outcry over China's opaque approach to FDI, it is unlikely that the BRI will reduce its expansion in Africa nor will there be extensive debt sustainability problems. However, instances where there have been identified issues of sustainability, it has been rather severe, suggesting that the initiative cannot completely avoid debt problems amongst participating nations.

For African nations to leverage on BRI's potential to their advantage, the African Union could endorse the engagements by creating a blueprint for key cross-country and regional projects to execute with China as the main partner (Dahir, 2019). What is more important is for global economic players to establish a clear distinction between detrimental and essential 
BRI engagements because it is crucial to fostering development, building common ground with China, and expanding the global market (Risberg, 2019). Realigning her lending practices along the lines of IMF can be a good way to manage the debt load of African nations under BRI while reducing the tensions between China and the West.

\section{Conclusion}

Many African nations gained independence in the late 1950s up to the 1960s; mostly relying on the former colonial masters to be development partners. Unfortunately, this has not happened, and Africa has largely lagged in infrastructure. While the West cries foul, nations that have benefitted from infrastructure projects from China, tend to view China as a viable partner because mainly because the latter does not impose funding conditions. The lack of political accountability has led to additional interest by corrupt African nations to continue to seek partnership with China, who is regarded as Africa's largest bilateral creditor. African governments owe Chinese state-owned enterprises an approximate US\$150 billion.

The COVID-19 pandemic is impeding BRI partner countries' ability to repay on their debt, thus leading to fears that these nations may either be ushered into debt-trap diplomacy with China or on a milder side, the Chinese lenders may play a longer game? (Furness, 2020). The G20 agreed to suspend debt payments for low-income countries due to the pandemic and there have been calls for China to do the same or forgive loans to Africa as well. Against the backdrop of the BRI, a health model to protect safety and wellbeing, a model of recovery to restore economic and social activities, and a model of growth to unleash development potential can only be achieved through unity and solidarity (Tianyuan, 2020).

Whether China's BRI engagements in Africa make or mar development appears to be a milder concern in the face of worries about the possible future conflict between China and the US. China's growth to a major economic power in just under four decades was perceived as spectacular, though it raised questions among many US policymakers (Morison, 2019). According to Danilova and Anna (2018), the US wants to see increased investment and trade in Africa as part of a new strategy aimed at countering Chinese growth in the continent. Critics are skeptical about this revived US interest in Africa because it took a long time for the present administration to announce the initiative; notably following the disparaging remarks by President Trump about the continent. China's investment strategy has generally been that of throwing money at developing nations. This approach seems to have hit a hurdle in the Republic of Congo where she sought a bailout from the IMF (Agence France-Presse, 2019). If implemented diligently, the BRI can be a success from the standpoint of completing the network of trade routes linking Africa, Asia, and Europe.

\section{Abbreviations}

AGOA: Africa Growth and Opportunity Act, BRI: Belt and Road Initiative, CHEC: China Harbor Engineering Corporation, COVID-19: Coronavirus, 2019, EIBC: Export-Import Bank of China, E.U.: European Union, FDI: Foreign Direct Investment, FOCAC: Forum on China Africa Cooperation, ICT: Information and Communication Technology, OBOR: One Belt, One Road, US: United States. 


\section{References}

Agence France-Presse, (2019). China's vast investment in Africa hits a snag in Congo. South China Morning Post. Retrieved August 22, 2020 from https://www.scmp.com/news/china/diplomacy/article/3007998/chinas-vast-investment-africahi ts-snag-congo

Anyu, J. N., \& Dzekashu, W. G. (2019). China's enterprise in Africa: Market entry strategies, implications for capacity building, and corporate social responsibility. Journal of Economics and Political economy, 6(2), 172-180. http://dx.doi.org/10.1453/jepe.v6i2.1898

Badu, S. (2019). Where we are doing the project.Eni.com. Retrieved July 18 from https://www.eni.com/en-IT/operations/ghana-octp.html

Belt \& Road News, (2019). China just quietly wrote off a chunk of Cameroon's debt: Why the secrecy? Belt and Road News. Retrieved July 30, 2020 from https://www.beltandroad.news/2019/02/06/china-just-quietly-wrote-off-a-chunk-of-cameroon s-debt/

Belt \& Road News, (2019). Ghana eyes Belt \& Road Initiative: Official for boosting major infrastructure development. Belt and Road News. Retrieved July 18, 2020 from https://www.beltandroad.news/2019/05/08/ghana-eyes-belt-road-initiative-official/

Benjelloun, W. (2015). China-Africa co-operation: Capacity building and social responsibility of investments. African Perspectives. Retrieved May 12, 2019 from https://media.africaportal.org/documents/saia_spi_24_benjelloun_20150917.pdf

Chen, Y. \& Landry, D. G. (2016). Capturing the rains: A comparative study of Chinese involvement in Cameroon's hydropower sector. Working Paper No. 2016/5. China Africa Research Initiative, School of Advanced International Studies, Johns Hopkins University. Retrieved June 10, 2020 from https://static1.squarespace.com/static/5652847de4b03 3f56d2bdc29/t/57ff9ca8e3df28f75af06913/1476369580891/cameroon+final+draft+6.pdf

Cheng, S., Fang, T., \& Lien, H.-T. (2012). China's International Aid Policy and its implications for global governance. RCCPB Working Paper, No.29. https://doi.org/10.2139/ssrn.2169863

Cook, M. (2019). This country recently became Africa's largest economy. Now it's too big for businesses to ignore. Brink. Retrieved October 4, 2020 from https://www.brinknews.com/this-country-recently-became-africas-largest-economy-now-its-t oo-big-for-businesses-to-ignore/\#: :text=Nigeria\%20has\%20overtaken $\% 20$ South $\% 20$ Africa, or\%20Egypt\%20(102\%20million)

Dahir, A. L. (2019). These are the African countries not signed to China's Belt and Road project. Quartz Africa. Retrieved July 12, 2020 from https://qz.com/Africa/1718826 /the-african-countries-not-signed-to-chinas-belt-and-road-plan/

Danilova, M., \& Anna, C., (2018). U.S. seeks to counter growing Chinese influence in Africa. Associated Press. Retrieved August 12, 2020 from https://www.business 
insider.com/ap-us-seeks-to-counter-growing-chinese-influence-in-africa-2018-12

Deng, Y. (2019). The sustainability challenge of China's BRI. East Asia Forum. Retrieved August 1 , $2020 \quad$ from https://www.eastasiaforum.org/2019/12/13/the-sustainability-challenge-of-chinas-bri/

Fitch Ratings, (2020). Fitch revises Cameroon's outlook to negative; affirms at 'B.' Retrieved September 24, 2020 from https://www.fitchratings.com/research/soverei gns/fitch-revises-cameroon-outlook-to-negative-affirms-at-b-22-04-2020

Focus Economics. (2020). Ghana Economic Outlook. Retrieved September 28, 2020 from https://www.focus-economics.com/countries/ghana

Furness, V. (2020). China's Belt and Road Initiative: Can Africa escape a debt trap? Euro Money. Retrieved July 31, 2020 from https://www.euromoney.com/article/b1lw rkkw wpxs0x/chinas-belt-and-road-initiative-can-africa-escape-a-debt-trap

Hurley, J., Morris, S., \& Portelance, G. (2018). Examining the debt implications of the Belt and Road Initiative from a policy perspective. Journal of Infrastructure, 3(1). http://dx.doi.org/10.24294/jipd.v3i1.1123

Jin, F. (2017). The belt and road initiative: Progress, problems, and prospects. Center for Strategic \& International Studies. Retrieved June 3, 2020 from https://www. csis.org/belt-and-road-initiative-progress-problems-and-prospects

Johns Hopkins University SAIS China Africa Research Initiative, (2020). Data: Chinese investment in Africa. China Africa Research Initiative, School of Advanced International Studies, Johns Hopkins University. Retrieved June 10, 2020 from http://www.sais-cari.org/s/FDIData_19Feb2020.xlsx

Kazeem Y. (2020). Here's how COVID-19 has battered Africa's largest economy. World Economic Forum. Retrieved September 28, 2020 from https://www.weforum .org/agenda/2020/08/africa-largest-economy-worst-contraction-in -a-decade/

Labuschagne, J.-P., Dedasaniya, M., Davies, M., \& Essop, N. (2018). Africa construction trends: If you want to prosper, first build roads. Africa construction in focus. Deloitte. $\begin{array}{llll}\text { Retrieved July } & 31, & 2020 & \text { from }\end{array}$ https://www2.deloitte.com/za/en/pages/energy-and-resources/articles/africa-construction-tren ds-report.html

McGregor, M., \& Havenga, A. (2019). China's growing reach in Africa: Are we seeing a fair trade? The Africa Report. Retrieved June 20, 2020 from https://www.theafricare port.com/17380/chinas-growing-reach-in-africa-are-we-seeing-a-fair-trade/\#: :text=Africa's $\% 20$ trade $\% 20$ with\%20China\%20grew,compound\%20annual\%20rate\%20of\% 2019\%25

Metwally, H. A. B. (2019). BRI: Six years of success in Africa. China.org.cn. Retrieved June 20, 2020 from http://www.china.org.cn/opinion/2019-04/25/content_74720 150.htm 
Morison, M. W. (2019). China's economic rise: History, trends, challenges, and implications for the United States. Congressional Research Services. Retrieved June 30, 2020 from https://crsreports.congress.gov/product/pdf/RL/RL33534

Nantulya, P. (2019). Implications for Africa from China's One Belt One Road Strategy. Africa Center for Strategic Studies. Retrieved July 1, 2020 from https://africacenter.org/spotlight/implications-for-africa-china-one-belt-one-road-strategy/

Nyabiage, J. (2020). Work begins on Nigeria's China-funded US\$2.8 billion gas pipeline. South China Morning Post. Retrieved from July 20, 2020 https://www.scmp.com/news/china/diplomacy/article/3091533/work-begins-nigerias-china -funded-us28-billion-gas-pipeline

Odutola, A. (2019). How the Chinese are taking over Nigeria's economy. Nairametrics. $\begin{array}{llll}\text { Retrieved } & \text { September } & 29, & \text { from }\end{array}$ https://nairametrics.com/2019/11/28/how-the-chinese-are-taking-over-nigerias-economy/

Orlander, E. (2019). China and Ghana agree to a small debt write-off and a big bauxite deal. The China Africa Project. Retrieved September 29, 2020 from: https://chinaafricaproject.com/about-cap/

Park, Y. J. (2009). Chinese Migration in Africa. China in Africa Project Occasional Paper, No 24. Retrieved July 31, 2020 from https://www.researchgate.net/publication/330533726_Chinese_Migration_in_Africa_Occasio nal_Paper_No_24

Radford, J. (2018). Nigeria awards $\$ 7$ bln rail project to Chinese state rail firm -Xinhua. Retrieved August 2, 2020 from https://fr.reuters.com/article/china-nigeria-idUSL5N 1SN00N

Risberg, P. (2019). The give-and-take of BRI in Africa. Center for Strategic \& International $\begin{array}{lllll}\text { Studies. } & \text { Retrieved } & \text { July } & 2020 & \text { from }\end{array}$ https://csis-prod.s3.amazonaws.com/s3fs-public/NewPerspectives_APRIL2019_Risberg.pdf

Schenkel, J. (2018). China-backed Kribi port project in Cameroon leaves locals frustrated. DW. $\quad$ Retrieved $\quad$ August $\quad 10, \quad 2020$ from https://www.dw.com/en/china-backed-kribi-port-project-in-cameroon-leaves-locals-frustrated /a-42016788

Shinn, D. H., (2018). China's economic impact on Africa. International Political Economy, World Politics. https://doi.org/10.1093/acrefore/9780190228637.013.831

Snyder, H. (2019). Literature review as a research methodology: An overview and guidelines. Journal of Business Research, 104, 333-339. https://doi.org/10.1016/j.jbusres.2019.07.039

Sun, Y. (2016). Political party training: China's ideological push in Africa. Africa in Focus. Retrieved August 15, 2020 from https://www.brookings.edu/blog/africa-in-focus/2016/07/05/political-party-training-chinas-id eological-push-in-africa/ 
Swaine, M. D. (2015). Chinese views and commentary on the "One Belt, One Road" Initiative. China Leadership Monitor, No. 47. Retrieved June 22, 2020 from https://www.hoover.org/research/chinese-views-and-commentary-one-belt-one-road

Tianyuan, S. (2020). China to advance Belt and Road cooperation despite COVID-19 impact. $\begin{array}{lllll}\text { CGTN. } & \text { Retrieved } & \text { August } & 1020 & \text { from }\end{array}$ https://news.cgtn.com/news/2020-06-18/China-to-advance-Belt-and-Road-cooperation-despit e-COVID-19-impacts-Rq HWEzf1qU/index.html

Trading Economics (2020). Nigeria GDP. Retrieved September 28, 2020. https://tradinge conomics.com/nigeria/gdp

Wee, B. V., \& Banister, D. (2015) How to write a literature review paper? Journal Transport Reviews, 36(2). https://doi.org/10.1080/01441647.2015.1065456

Xinhua. (2019). Ghana eyes BRI for boosting major infrastructure development: Official. $\begin{array}{lllll}\text { XinhuaNet. } & \text { Retrieved July } & 31, & 2020 & \text { from }\end{array}$ http://www.xinhuanet.com/english/2019-05/07/c_138040732.htm

Zhai, F. (2017). China's Belt and Road initiative: A preliminary quantitative assessment. Journal of Asian Economics, 55, 84-92. https://doi.org/10.1016/j.asieco.2017.12.006

\section{Copyright Disclaimer}

Copyright for this article is retained by the author(s), with first publication rights granted to the journal.

This is an open-access article distributed under the terms and conditions of the Creative Commons Attribution license (http://creativecommons.org/licenses/by/4.0/). 